\title{
Real-Time PCR and LAMP Assays for the Detection of Spores of Alternaria solani and Sporangia of Phytophthora infestans to Inform Disease Risk Forecasting
}

\author{
A. K. Lees, ${ }^{\dagger}$ D. M. Roberts, J. Lynott, L. Sullivan, and J. L. Brierley \\ The James Hutton Institute, Invergowrie, Dundee DD2 5DA, United Kingdom
}

Abstract

\begin{abstract}
Real-time loop-mediated isothermal amplification (LAMP) assays for the detection of sporangia of the causal pathogen of late blight, Phytophthora infestans, and spores of the main causal pathogen of early blight, Alternaria solani, were developed to facilitate the in-field detection of airborne inoculum to improve disease forecasting. These assays were compared with an existing real-time PCR assay for P. infestans and a newly developed real-time PCR assay for A. solani. Primers were designed for real-time LAMP of $P$. infestans and $A$. solani. The specificity of the $P$. infestans real-time LAMP assay was similar to that of an existing real-time PCR assay: DNA of $P$. infestans was consistently amplified as was DNA of the taxonomically closely related species Phytophthora mirabilis, Phytophthora phaseoli, and Phytophthora ipomoea; no amplification of DNA from the potato pathogens Phytophthora erythroseptica or Phytophthora nicotianae occurred. Real-time LAMP and PCR assays were developed for $A$. solani, and the specificity was compared with an existing conventional PCR assay. Importantly, the $A$. solani real-time LAMP and PCR assays did not amplify the species Alternaria
\end{abstract}

alternata. However, cross-reactivity with Alternaria dauci was observed with the real-time PCR assay and Alternaria brassicae with the real-time LAMP assay. The sensitivity of all assays for the detection of DNA extracted from sporangia/spores of the target pathogens was evaluated. The $P$. infestans real-time LAMP assay reliably detected $5 \mathrm{pg}$ of DNA, equivalent to $\sim 1$ sporangia per reaction. By comparison, $20 \mathrm{fg}$ of DNA was detectable with the existing real-time PCR assay. In the case of $A$. solani, real-time LAMP detected $4.4 \mathrm{pg}$ of DNA, equivalent to $\sim 1$ spore per reaction, and real-time PCR detected $200 \mathrm{fg}$ of DNA. In-field air samplers were deployed in two trial plots planted with potato: one infected with $P$. infestans, and the other infected with $A$. solani. Four additional samplers were located in commercial potato fields. Air samples were taken through the season, and detection of airborne inoculum of $P$. infes tans and A. solani with both real-time PCR and LAMP was assessed.

Keywords: air sampling, fungi, IPM, oomycetes, pathogen detection, rotating air samplers
Early and late blight of potato caused by species of the fungal pathogen Alternaria and the oomycete pathogen Phytophthora infestans, respectively, can cause significant crop losses (Haverkort et al. 2008; Yellareddygari et al. 2018). Both are aerially transmitted and controlled by intensive fungicide regimes. Ideally, management options could be tailored to control both pathogens in combination.

Early blight is considered to be predominantly caused by Alternaria solani Sorauer in Europe, although Alternaria alternata (Fries) Keissler, which also causes brown spot, is implicated. Several other Alternaria species, including Alternaria tenuissima, Alternaria arborescens, Alternaria infectoria, and Alternaria grandis, have been associated with foliar disease symptoms on potato worldwide (Ardestani et al. 2010; Rodrigues et al. 2010; Zheng et al. 2014). Similarly, Alternaria species associated with other crops may be present in the vicinity of potatoes. Symptoms are often observed initially on older, senescing leaves and are characteristically dark brown or black lesions with concentric rings on leaves, which produce a "target spot" effect.

Early blight is widespread in potato- and tomato-growing areas, and it is especially prevalent in temperate zones. The disease has occurred with increasing frequency in northern European potatogrowing areas (Edin 2012; Leiminger and Hausladen 2012;

\section{${ }^{\dagger}$ Corresponding author: A. K. Lees; Alison.Lees@hutton.ac.uk}

Funding: This work was carried out with funding from InnovateUK grant 102099 and supported by the Rural and Environment Science and Analytical Services Division of the Scottish Government.

*The $\boldsymbol{e}$-Xtra logo stands for "electronic extra" and indicates that one supplementary table is published online.

The author(s) declare no conflict of interest.

Accepted for publication 25 June 2019.

(C) 2019 The American Phytopathological Society
Runno-Paurson et al. 2015). In the United Kingdom, there has been increasing concern regarding the frequency and severity of early blight outbreaks. Reasons for this could include warmer prevailing temperatures favoring the pathogen, changes in fungicide use, or an increase in the area of susceptible varieties grown. It is known that host resistance to early blight exists and is heritable (Odilbekov et al. 2014; Stewart et al. 1994); however, information on varietal resistance for early blight in commercially grown varieties is not readily available.

Worldwide, crop losses due to early blight in the range 5 to $78 \%$ have been reported in untreated crops. Fungicide costs for the control of early blight are difficult to calculate accurately, as Alternaria spp. belong to a complex of tomato/potato pathogens that are often controlled using the same products. However, according to Kemmitt (2002), the estimated expenditure on fungicides for control of Alternaria spp. globally is around $\$ 32$ million annually in tomatoes and $\$ 45$ million in potatoes. According to Leiminger and Hausladen (2012), fungicides to control early blight are applied regardless of existing disease levels or disease-favorable weather conditions, and this strategy may result in superfluous or ineffective fungicide applications. Managing the use of fungicides for the control of early blight is important because $A$. solani poses a high risk in terms of the development of fungicide resistance (Leiminger et al. 2014). For example, reduced sensitivity of $A$. solani to quinone outside inhibiting (QoI) fungicides has been reported in the United States (Pasche and Gudmestad 2008) and Europe (Edin and Andersson 2014; Leiminger et al. 2014), and resistance to the succinate dehydrogenase inhibitor fungicide boscalid has been reported in the United States (Gudmestad et al. 2013; Wharton et al. 2012). Inoculum of A. solani is primarily dispersed within and between fields owing to the prevailing weather and wind and can also originate from seedborne infections, residual plant debris, or other solanaceaous hosts (Rosenzweig et al. 2008). Decision support systems that forecast favorable weather for infection by Alternaria spp. are used in some countries to manage early blight but do not consider the presence or absence of inoculum. Leiminger and Hausladen (2012) demonstrated that it is not necessary to apply early blight control throughout the season, because 
disease could be adequately controlled with only a few fungicide applications using threshold values based on disease progress.

Late blight of potato caused by $P$. infestans continues to be a major constraint to potato production in Europe and other key crops, including tomato and other solanaceous plants, worldwide. Both control costs and crop loss contribute to economic losses: Haverkort et al. (2008) estimated that $15 \%$ of the farm-gate value of the potato crop is lost through late blight, representing losses in the region of $€ 900$ million across the European Union.

$P$. infestans inoculum may originate from seedborne infections, volunteers, cull piles, and alternative hosts. Under optimal environmental conditions, the pathogen can complete several infection cycles a week on a susceptible host, potentially producing very large quantities of sporangia. As a result of wind dispersal of the sporangia and the potentially large number of generations, a late blight epidemic can quickly spread over large regions (Zwankhuizen and Zadoks 2002). The formation, release, and escape of spores from the canopy, the direction and extent of spore dispersal, the survival and deposition of spores, and the ability of spores to infect are determined by weather conditions (Skelsey et al. 2010).

Host resistance offers great potential for late blight control, but the durability of resistance conferred by $\mathrm{R}$ genes is continually challenged due to the evolution of virulence traits within the pathogen population (Fry 2008). In northwest Europe, varieties with greater resistance tend not to be grown on a large scale owing to end-user preference for varieties with specific agronomic characteristics (Cooke et al. 2011). The relatively recent emergence of an aggressive lineage of $P$. infestans able to overcome previously effective forms of plant host resistance and fungicides is discussed in some detail by Cooke et al. (2012).

Potato production is dependent on the repeated use of fungicides throughout the growing season for the control of late blight. Choice of products within a spray program and minimum intervals between applications are important considerations. There is pressure to reduce the use of fungicides, and therefore their environmental and economic costs, through increasing adoption of integrated pest management. The integrated control of potato late blight in Europe was previously reviewed by Cooke et al. (2011), who stressed the need for antiresistance management of existing active ingredients, deployment of durable host resistance, and the use of decision support systems to improve timing of fungicide applications and allow fungicide use to be adjusted according to cultivar resistance and infection pressure.

The aerial dispersal of pathogen inoculum to uninfected hosts is crucial to the epidemic phase of many crop diseases (Skelsey and Newton 2015; Skelsey et al. 2009). However, incoming inoculum is largely ignored in crop disease risk assessments. This is in part due to the peculiarities of the weather and the complexity involved in identifying sources of inoculum (Spitters et al. 1989). It is, therefore, generally assumed that inoculum is ubiquitous and occurs at levels able to cause disease. The future risk of disease under these assumptions is, therefore, only dependent on the occurrence of local conditions conducive for infection. Detection of airborne inoculum in-field is, therefore, increasingly being recognized as a key factor missing from decision support systems to inform early and late blight management strategies (Fall et al. 2015a).

Real-time PCR assays are both sensitive and specific in their ability to detect and quantify target DNA, but they generally require thermocyclers and are better suited to laboratory use. Loop-mediated isothermal amplification (LAMP) is a simple, rapid, and specific nucleic acid amplification method. It is characterized by the use of four or six different primers specifically designed to recognize six distinct regions on the target gene, and the reaction process proceeds at a constant temperature using strand displacement reaction (Notomi et al. 2000). Amplification and detection of target DNA can be completed in a single step by incubating at a constant temperature. Isothermal amplification techniques, including LAMP, have the advantage over real-time PCR techniques in that they do not require thermocyclers, making them suitable for incorporation into in-field detection devices.

Previously published methods of detecting A. solani and A. alternata by PCR include conventional PCR assays (Pavón et al. 2012;
Zur et al. 2002), a conventional PCR assay combined with detection of the F129L substitution associated with loss of sensitivity to QoI fungicides in A. solani (Edin 2012), real-time assays for the discrimination of single-nucleotide polymorphisms related to loss of fungicide sensitivity in A. solani (Rosenzweig et al. 2008), and in planta quantification of $A$. solani and A. alternata (Leiminger et al. 2015). Conventional PCR assays for the detection of $P$. infestans are also available (Hussain et al. 2005; Judelson and Tooley 2000). Moreover, real-time PCR assays for $P$. infestans have been developed (Böhm et al. 1999; Fall et al. 2015b; Lees et al. 2012; Llorente et al. 2010). Only the assays developed by Fall et al. (2015b) and Lees et al. (2012) were tested for both sensitivity and specificity, and the two assays are comparable.

The objective of this work was to develop diagnostics suitable for in-field monitoring of $P$. infestans and $A$. solani inoculum and to demonstrate their ability to detect airborne sporangia/spores with a view to incorporating inoculum detection into existing weatherbased forecasting systems for early and late blight. The aim thereafter would be to improve predictions of disease risk and inform the initiation of fungicide applications for disease control. There is scope to carry out additional research to optimize the combined control of late blight and early blight in an integrated system.

\section{Materials and Methods}

Isolates and cultures. Twenty-eight isolates of Phytophthora species from various hosts, including $P$. infestans isolates from potato and one isolate of Pythium ultimum (Table 1), were supplied by David Cooke (The James Hutton Institute). Thirty-one isolates of the genus Alternaria were used for assay development and comparison (Table 2). These included 18 isolates of $A$. solani, nine isolates of A. alternata, and one isolate each of the species Alternaria dauci, Alternaria tenuissima, Alternaria brassicicola, and Alternaria brassicae as representatives of species that could also be present in potato-growing areas. Additionally, specificity testing of the $A$. solani assays was carried out with one isolate of each of eight common potato pathogens: $P$. infestans, Rhizoctonia solani, Colletotrichum coccodes, Helminthosporium solani, Fusarium culmorum, Fusarium sambucinum, Fusarium avenaceum, and Fusarium coeruleum.

Extraction of DNA from mycelium and sporangia/spores. Isolates of Phytophthora species were grown on rye A agar or pea agar incubated at $18^{\circ} \mathrm{C}$ for 7 days, and isolates of the genus Alternaria and other species were grown on potato dextrose agar incubated at $20^{\circ} \mathrm{C}$ for 10 days. A 6- $\mathrm{mm}^{2}$ plug was then taken from the edge of the colony and used to inoculate $20 \mathrm{ml}$ of pea broth (Phytophthora spp.) or potato dextrose broth (other species) in a sterile 9-cm Petri dish. After 10 days of incubation at 18 or $20^{\circ} \mathrm{C}$, respectively, the agar plug was discarded, and the resulting mycelium was washed in sterile distilled water and dried on a paper towel. A 0.1-g sample of mycelium was weighed and freeze dried in a 1.5-ml Eppendorf tube overnight.

For $P$. infestans sporangial production, leaves of potato cultivar Estima were inoculated with a sporangial suspension of an isolate of $P$. infestans and incubated in a damp chamber for 7 days at $15^{\circ} \mathrm{C}$, after which the sporangia were washed off the leaves using sterile distilled water. Spores of Alternaria species were produced by incubating cultures at $20^{\circ} \mathrm{C}$ in an incubator set at 16 -h light and 8-h dark or under ultraviolet light (Philips Ltd 36W/80) with an alternating 12-h photoperiod. Spores were removed using a glass rod by washing the plate with sterile distilled water.

The concentration of the sporangial/spore suspensions was measured using a hemocytometer and adjusted to 8,000 spores per $1 \mu 1$. Suspensions were then freeze dried in 1.5-ml Eppendorf tubes. DNA was extracted from freeze-dried mycelia and sporangia using a method modified from Raeder and Broda (1985): weight of the starting material was reduced to $30 \mathrm{mg}$, and the volume of reagents was increased to $150 \%$ of the original. DNA concentration (nanograms per microliter) was quantified using a Nanodrop spectrophotometer ND-1000 (Thermo Fisher Scientific).

$A$. solani and $P$. infestans real-time PCR assays. To develop a real-time PCR assay for $A$. solani, multiple sequence alignments of the ITS1 and ITS2 regions of $A$. solani and A. alternata were 
examined for regions potentially unique to $A$. solani. Primer Express Software version 3.0 (Thermo Fisher Scientific) was used to design a unique set of primers AsolTQF (5'-GGTGTTGGGCGTCTTTTTG-3') and AsolTQR (5'-GCTAGACCTTGGGGCTGGA-3') with an amplification product of $119 \mathrm{bp}$ and a fluorogenic probe AsolTQP (5'TCCCCTTGCGGGAGA-3') based on regions of the greatest sequence dissimilarity among species after the alignment of ITS1 sequences (A. solani GenBank accession no. EU617674.1). The fluorogenic probe (AsolTQP) was labeled at the $5^{\prime}$ end with the fluorescent reporter dye 6-carboxy-fluoroscein, and the $3^{\prime}$ end was modified with a black hole quencher (Eurofins Genomics).

A previously described real-time PCR assay for $P$. infestans (Lees et al. 2012) was used for comparison of the $P$. infestans assays.

Real-time PCR amplification was carried out according to the methods described by Lees et al. (2012). Reaction components for quantitative real-time PCR were obtained from the Applied Biosystems Taqman Universal PCR Mastermix (Fisher Scientific), and the reaction was performed in MicroAmp optical 96-well plates using the StepOnePlus Real-Time PCR System (Applied Biosystems). Primers PinfTQF/PinfTQR or AsolTQF1/AsolTQR1 were included at a final concentration of $0.3 \mu \mathrm{M}$ per reaction, and Taqman probe PinfTQPR or AsolTQP was used at $0.1 \mu \mathrm{M}$ in a total reaction volume of $25 \mu \mathrm{l}$, which was shown previously to be optimal by primer and probe optimization tests. The recommended generic (three-stage) thermal cycle protocol was used for PCR amplification (Applied Biosystems): $50^{\circ} \mathrm{C}$ for $2 \mathrm{~min} ; 95^{\circ} \mathrm{C}$ for $10 \mathrm{~min}$; and 40 cycles of $95^{\circ} \mathrm{C}$ for $0.15 \mathrm{~s}$ and $60^{\circ} \mathrm{C}$ for $60 \mathrm{~s}$. The annealing temperature was set at $60^{\circ} \mathrm{C}$ for $A$. solani and $61^{\circ} \mathrm{C}$ for the $P$. infestans assay for increased specificity.

Threshold cycle $(\mathrm{Ct})$ value is defined as the cycle number at which a statistically significant increase in the reporter fluorescence (i.e., exceeds the threshold) is first detected, and it is dependent on the input of starting copies of target. The starting concentration of target sequence was calculated by comparing $\mathrm{Ct}$ values of unknown samples with the $\mathrm{Ct}$ values of duplicate standard DNA samples extracted from mycelium, from which a 10-fold serial dilution was made: $10 \mathrm{ng} / \mu \mathrm{l}$ to $100 \mathrm{fg} / \mu \mathrm{l}$. Ct values were plotted against the $\log$ of the initial concentration of DNA to produce a standard curve. The Ct values for each PCR reaction were interpolated from the standard curves to calculate the amount of $P$. infestans or A. solani target DNA in a sample. Nontemplate controls were run in triplicate using $2 \mu \mathrm{l}$ of HPLC-grade water instead of DNA during every run. All samples were tested in duplicate, and results show the mean values generated.

The specificity of the $A$. solani real-time PCR assay was tested against genomic DNA ( $10 \mathrm{ng} / \mu \mathrm{l})$ of 39 different isolates: 18 isolates of $A$. solani, nine isolates of the closely related species A. alternata, four isolates of other Alternaria spp., and eight isolates of other

Table 1. Isolate details and detection (+/-) of isolates of Phytophthora species and Pythium ultimum used for specificity testing of the real-time loop-mediated isothermal amplification (LAMP) assay compared with existing real-time PCR assay (Lees et al. 2012)

\begin{tabular}{|c|c|c|c|c|}
\hline \multirow[b]{2}{*}{ Species (Hutton isolate code) } & \multirow[b]{2}{*}{ Host } & \multirow[b]{2}{*}{ Country of origin } & \multicolumn{2}{|c|}{ Amplification detected } \\
\hline & & & Real-time PCR & Real-time LAMP \\
\hline Phytophthora infestans (2009_7454A) & Potato & United Kingdom & + & + \\
\hline Phytophthora infestans (2009_7654A) & Potato & United Kingdom & + & + \\
\hline Phytophthora alni (SCRP16a) & Alder & United Kingdom & - & - \\
\hline Phytophthora cambivora (SCRP69 ${ }^{\text {b }}$ ) & Raspberry & United Kingdom & - & - \\
\hline Phytophthora citophthora (SCRP188') & Unknown & China & - & - \\
\hline Phytophthora cryptogea $\left(\mathrm{SCRP} 205^{\mathrm{d}}\right)$ & Potato & Ireland & - & - \\
\hline Phytophthora drechsleri (SCRP232a & Beet & United States & - & - \\
\hline Phytophthora erythroseptica $\left(\mathrm{SCRP} 1170^{\mathrm{e}}\right)$ & Unknown & Unknown & - & - \\
\hline Phytophthora fragariae $\left(\mathrm{SCRP} 245^{\mathrm{b}}\right)$ & Strawberry & United Kingdom & - & - \\
\hline Phytophthora fragariae var. rubi (SCRP333 $\left.{ }^{\mathrm{b}}\right)$ & Raspberry & United Kingdom & - & - \\
\hline Phytophthora gonapodyides (SCRP1163 $\left.{ }^{\mathrm{b}}\right)$ & Unknown & United Kingdom & - & - \\
\hline Phytophthora idaei (SCRP370 ${ }^{\mathrm{b}}$ ) & Raspberry & United Kingdom & - & - \\
\hline Phytophthora ilicis (SCRP377a) & Holly & United Kingdom & - & - \\
\hline Phytophthora insolita $\left(\mathrm{SCRP}^{2} 5^{\mathrm{c}}\right)$ & Unknown & Taiwan & - & - \\
\hline Phytophthora inundata (SCRP951 $)$ & Olive & Spain & - & - \\
\hline Phytophthora ipomoea (SCRP1168e) & Morning glory & Mexico & + & + \\
\hline Phytophthora castaneae (SCRP3889) & Unknown & Unknown & - & - \\
\hline Phytophthora kernoviae (SCRP957ª) & Beech & United Kingdom & - & - \\
\hline Phytophthora lateralis $\left(\mathrm{SCRP} 390^{c}\right)$ & Lawson cypress & United States & - & - \\
\hline Phytophthora megasperma (SCRP417b) & Raspberry & United Kingdom & - & - \\
\hline Phytophthora mirabilis (SCRP1167e) & Four o'clock flower & Mexico & + & + \\
\hline Phytophthora nicotianae (SCRP1160 $)$ & Tobacco & China & - & - \\
\hline Phytophthora palmivora (SCRP474a) & Coconut & Ivory Coast & - & + \\
\hline Phytophthora phaseoli (DNA) & Bean & Unknown & + & + \\
\hline Phytophthora plurivora (SCRP383 ${ }^{\mathrm{d}}$ ) & Syringa & Unknown & $\mathrm{nt}^{\mathrm{i}}$ & - \\
\hline Phytophthora quercina (SCRP540 ) & White oak & Germany & - & - \\
\hline Phytophthora ramorum (SCRP954a) & Viburnum & United Kingdom & - & - \\
\hline Phytophthora pseudosyringae (SCRP734k) & Beech & Italy & - & - \\
\hline Pythium ultimum (SCRP1200') & Potato & United Kingdom & nt & - \\
\hline
\end{tabular}

\footnotetext{
${ }^{a}$ Isolates were supplied by Clive Brasier, Forest Research, United Kingdom.

b Isolates were supplied by The James Hutton Institute, United Kingdom.

${ }^{\mathrm{c}}$ Isolates were supplied by CABI Bioscience, United Kingdom.

d Origin unknown.

e Isolates were supplied by Wageningen University, The Netherlands.

f Isolates were supplied by Jozsef Bakonyi, Plant Protection Institute, Hungarian Academy of Sciences.

${ }^{\mathrm{g}}$ Isolates were supplied by Frank Panabiere, INRA, France.

${ }^{\mathrm{h}}$ Isolates were supplied by Weixing Shan, Northwest A\&F University, China.

i Not tested.

j Isolates were supplied by Bavarian State Institute of Forestry, Germany.

${ }^{\mathrm{k}}$ Isolates were supplied by Santina Cacciola, University of Catania, Italy.
} 
potato pathogens (Table 2). To test the sensitivity of spore detection using the A. solani real-time PCR assay, a standard curve was prepared as follows: DNA was extracted from a suspension of known spore concentration $(8,000$ spores per $1 \mu \mathrm{l})$, and a serial dilution of the DNA was made to the equivalent of $200,20,2,0.2$, and 0.02 spores per $1 \mu \mathrm{l}$.

LAMP assay primer design. LAMP primers based on the ITS1 and ITS2 sequence of a range of Phytophthora spp. and Alternaria isolates were designed to detect $P$. infestans (PinfL) and $A$. solani (AsolL). Sequences of the ITS region of $P$. infestans were compared with the potato-infecting species Phytophthora erythroseptica and Phytophthora nicotiana to identify potential regions specific to $P$. infestans. Similarly, ITS sequences from A. solani and A. alternata isolates were compared to identify regions able to discriminate these species. Sequences of the genera Phytophthora and Alternaria used for primer design are listed in Supplementary Table S1. Primer design was carried out using LAMP Designer (Optigene). The six LAMP primers (external primers F3 and B3, internal primers FIP and BIP, and loop primers F loop and B loop) (Fig. 1 and Table 3) were synthesized by Eurofins Genomics.

Real-time LAMP specificity and sensitivity. Real-time LAMP assays were carried out in a final reaction volume of $25 \mu \mathrm{l}: 15 \mu \mathrm{l}$ of Isothermal Master Mix ISO-001 containing a fluorescent double-stranded-DNA binding dye (Optigene), $5 \mu$ l of primer mix consisting of external primers (F3 and B3) at $5 \mu \mathrm{M}$, internal primers (FIP and BIP) at $20 \mu \mathrm{M}$, loop primers (F loop and B loop) at $10 \mu \mathrm{M}$ final concentration, and $5 \mu$ of DNA. Real-time LAMP was carried out using a StepOnePlus-System (Applied Biosystems). Reactions were incubated at $65^{\circ} \mathrm{C}$ for $40 \mathrm{~min}$, and the product was visualized every $30 \mathrm{~s}$ using FAM detection channel.

The specificity of the PinfL primers was tested against genomic DNA (10 ng/ $\mu$ l) of 28 different Phytophthora species and for AsolL

Table 2. Isolate details and detection (+/-) of Alternaria species and other potato pathogens with either an Alternaria solani real-time loop-mediated isothermal amplification (LAMP) assay or an A. solani real-time PCR assay compared with an existing conventional A. solani-specific PCR assay (Zur et al. 2002)

\begin{tabular}{|c|c|c|c|c|c|c|}
\hline Species (isolate code) & Country of origin & Host & $\begin{array}{c}\text { PCR } \\
\text { A. solani }\end{array}$ & $\begin{array}{c}\text { PCR Alternaria } \\
\text { alternata }\end{array}$ & $\begin{array}{c}\text { Real-time } \\
\text { PCR A. solani }\end{array}$ & $\begin{array}{c}\text { Real-time } \\
\text { LAMP } A \text {. solani }\end{array}$ \\
\hline A. solani (A.s Pol $\left.{ }^{\mathrm{a}}\right)$ & Poland & Solanum tuberosum & + & - & + & + \\
\hline A. solani $\left(\right.$ A.s $\left.1^{\mathrm{b}}\right)$ & Sweden & S. tuberosum & + & - & + & + \\
\hline A. solani $\left(\right.$ A.s $\left.13-1^{\mathrm{c}}\right)$ & United States & S. tuberosum & + & - & + & + \\
\hline A. solani (A.s 526-3c) & United States & S. tuberosum & + & - & + & + \\
\hline A. solani $\left(\right.$ A.s $\left.1178-W 1^{\mathrm{c}}\right)$ & United States & S. tuberosum & + & - & + & + \\
\hline A. solani $\left(\right.$ A.s $\left.1178-E 1^{\mathrm{c}}\right)$ & United States & S. tuberosum & + & - & + & + \\
\hline A. solani (A.s 1172-6' $)$ & United States & S. tuberosum & + & - & + & + \\
\hline A. solani (A.s 1179-13 ${ }^{\mathrm{c}}$ ) & United States & S. tuberosum & + & - & + & + \\
\hline A. solani (A.s 1174-9c) & United States & S. tuberosum & + & - & + & + \\
\hline A. solani (A.s $1246-15^{\mathrm{c}}$ ) & United States & S. tuberosum & + & - & + & + \\
\hline A. solani $\left(\right.$ A.s $\left.1185-7^{\mathrm{c}}\right)$ & United States & S. tuberosum & + & - & + & + \\
\hline A. solani $\left(\right.$ A.s $\left.121^{\mathrm{d}}\right)$ & Germany & S. tuberosum & + & - & + & + \\
\hline A. solani $\left(\right.$ A.s $\left.3161^{\mathrm{e}}\right)$ & Israel & S. tuberosum & + & - & + & + \\
\hline A. solani $\left(\right.$ A.s $\left.3111^{\mathrm{e}}\right)$ & Israel & S. tuberosum & + & - & + & + \\
\hline A. solani $\left(F M 28^{\mathrm{f}}\right)$ & United Kingdom & S. tuberosum & + & - & + & + \\
\hline A. solani $\left(F V L l 1^{\mathrm{f}}\right)$ & United Kingdom & S. tuberosum & + & - & + & + \\
\hline A. solani $\left(J 15^{\mathrm{f}}\right)$ & United Kingdom & S. tuberosum & + & - & + & + \\
\hline A. solani $\left(J 8^{\mathrm{f}}\right)$ & United Kingdom & S. tuberosum & + & - & + & + \\
\hline Alternaria alternata $\left(\right.$ A. $\left.a 2^{\mathrm{g}}\right)$ & United States & S. tuberosum & - & + & - & - \\
\hline Alternaria alternata (A.a $\left.3^{\mathrm{g}}\right)$ & United States & S. tuberosum & - & + & - & - \\
\hline Alternaria alternata $\left(\right.$ A.a Pol2 $\left.{ }^{\mathrm{a}}\right)$ & Poland & S. tuberosum & - & + & - & - \\
\hline Alternaria alternata $\left(A . a 3 e^{\mathrm{b}}\right)$ & Sweden & S. tuberosum & - & + & - & - \\
\hline Alternaria alternata $\left(\right.$ A. $\left.a 4^{\mathrm{b}}\right)$ & Sweden & S. tuberosum & - & + & - & - \\
\hline Alternaria alternata $\left(\right.$ A. a $\left.135^{\mathrm{d}}\right)$ & Germany & S. tuberosum & - & + & - & - \\
\hline Alternaria alternata $\left(\right.$ A.a $\left.210^{\mathrm{d}}\right)$ & Germany & S. tuberosum & - & + & - & - \\
\hline Alternaria alternata $\left(\right.$ A.a $\left.299^{\mathrm{d}}\right)$ & Germany & S. tuberosum & - & + & - & - \\
\hline Alternaria alternata $\left(130^{\mathrm{h}}\right)$ & United Kingdom & S. tuberosum & - & + & - & - \\
\hline Alternaria dauci $\left(143122^{\mathrm{i}}\right)$ & Cyprus & Daucus carota & + & - & + & - \\
\hline Alternaria tenuissima $\left(352931^{\mathrm{i}}\right)$ & United Kingdom & Genus Poaceae & - & - & - & + \\
\hline Alternaria brassicicola $\left(145549^{\mathrm{i}}\right)$ & United Kingdom & Brassica oleracea & - & - & - & - \\
\hline Alternaria brassicae $\left(289963^{\mathrm{i}}\right)$ & United States & B. oleracea & - & - & - & + \\
\hline Phytophthora infestans $\left(7654 A^{\mathrm{j}}\right)$ & United Kingdom & S. tuberosum & - & - & - & - \\
\hline Rhizoctonia solani AG3 (R150 $)$ & United Kingdom & S. tuberosum & - & - & - & - \\
\hline Colletotrichum coccodes $\left(C c 130^{\mathrm{j}}\right)$ & United Kingdom & S. tuberosum & - & - & - & - \\
\hline Helminthosporium solani $\left(\mathrm{H} 35^{\mathrm{j}}\right)$ & United Kingdom & S. tuberosum & - & - & - & - \\
\hline Fusarium culmorum $\left(F 75^{\mathrm{h}}\right)$ & United Kingdom & S. tuberosum & - & - & - & - \\
\hline Fusarium sambucinum $($ F196 $)$ & United Kingdom & S. tuberosum & - & - & - & - \\
\hline Fusarium avenaceum $\left(F 170^{\mathrm{h}}\right)$ & United Kingdom & S. tuberosum & - & - & - & - \\
\hline Fusarium coeruleum $\left(F 270^{\mathrm{h}}\right)$ & United Kingdom & S. tuberosum & - & - & - & - \\
\hline
\end{tabular}

a Isolates were supplied by Józefa Kapsa, IHAR, Poland.

${ }^{\mathrm{b}}$ Isolates were supplied by Eva Edin, Swedish University of Agricultural Sciences, Sweden.

c Isolates were supplied by Neil Gudmestad, North Dakota State University, U.S.A.

d Isolates were supplied by Gerd Stammler, BASF, Germany.

e Isolates were supplied by Leah Tsror, Gilat Research Centre, Israel.

${ }^{\mathrm{f}}$ Isolates were supplied by Jane Thomas, NIAB, United Kingdom.

$\mathrm{g}$ Isolates were supplied by Willie Kirk, Michigan State University, U.S.A.

${ }^{\mathrm{h}}$ Isolates were supplied by Science \& Advice for Scottish Agriculture, United Kingdom.

i Isolates were supplied by CABI, United Kingdom.

j Isolates were supplied by The James Hutton Institute, United Kingdom. 
primers against 31 Alternaria isolates and eight other potato pathogens. To test real-time LAMP assay sensitivity, DNA was extracted from suspensions of known spore (A. solani) or sporangial $(P$. infestans) concentration, and a serial dilution of the DNA was made to the equivalent of $0.1,1,10,100,1,000$, and 10,000 A. solani spores per reaction and $0.01,0.1,1,10,100,1,000$, and 10,000 $P$. infestans sporangia per reaction. At least four replicate DNA dilutions were tested. Nontemplate controls were tested in triplicate using $5 \mu l$ of HPLC-grade water in place of DNA during every run. All samples were tested in duplicate, and results show the mean values generated.

Use of rotating air sampler for in-field detection of $P$. infestans and $A$. solani spores. Control samples were used to measure the efficiency of detection of spores in the sampler to be used in the field; four replicate $100-\mu l$ sporangial suspensions of $P$. infestans (containing $1,5,10,20$, and 100 sporangia) or $A$. solani spore suspensions (containing 1, 5, 10, 20, 100, and 500 spores) were added to 2-ml screw-cap tubes each containing two Perspex arms coated with
Vaseline, as used in the rotating sampler. A water-only control was also set up. DNA was extracted from the samples using the MASTERPURE TM Yeast DNA purification kit (Cambio). P. infestans and $A$. solani in extracted DNA samples were then detected using the real-time LAMP assay and quantified using the real-time PCR assay.

A field plot of potato cultivar Maris Piper (10 rows of 21 plants with 50-cm spacing between plants) was planted on 3 May 2016 at a site at The James Hutton Institute (Dundee, United Kingdom). A rotating air sampler was placed in the center of the trial on 1 July. The air sampler was set to operate $2 \mathrm{~min}$ on, 2 min off for a $24-\mathrm{h}$ period at 3- to 4-day intervals until 18 August. Air samples were collected using rotating arm samplers, which captured airborne particles on sticky arms created by applying a thin smear of Vaseline onto the leading edge of each of two rotating Perspex arms. The arms rotated clockwise at 2,500 rpm, with air pulled in from below the rotating arms and thrown outward through vents in a rain shield, therefore sweeping a new piece of air with each rotation. They were

A

F3_PI1

F2 (FIP PI1)

5' -CCACACCTAAAAACTTTCCACGIGAACCGTTTCAACCCAAIA ATTGGGGGTCTTACTTGGCGGCGGCTGCTGGCTTTATTGCTGGCGGCTACTGCTGGGCGAG-3' 5' -GGTGTGGATTTTTGAAAGGTGCACTTGGCAAAGTTGGGTTATCAACCCCCAGAATGAACCGCCGCCGACGACCGAAATAACGACCGCCGATGACGACCCGCTC-3'

B1c (BIP_PI1)

5' -CCCTATCAAAAGGCGAGCGTTTGGACTTCGGTCTGAGCTAGTAGCTTTTTTATTTTAAACCCTTTACTTAATA_CTGATTATACTGTGGGGACGAAAGTOTCTG-3' 5' -GGGATAGTTTCCGCTCGCAAACdTGAAGCCAGACTCGATCATCGAAAAAATAAAATTTGGGAAATGAATTATGACTAATATGACACCCCTGCTTTCAGAGAC-3' LoopB_Pl1

5' - CTTTTAACTAGATAGCAACTTTCAGCAGTGGATGTCTAGGCTCGCACATCGATGAAGAACGCTGCGAACTGCGATACGTAATGCGAATTGCAGGATTCAGTGA-3' 5' -GAAAATTGATCTATCGTTGAAAGTCGTCACqTACAGATCCGAGCGTGTAGCTACTTCTTGCGACGCTTGACGCTATGCATTACGCTTAACGTCCTAAGTCACT-3' B2 (BIP_PI1) B3_Pl1

B

F3_Asol2

F2 (FIP_Asol2)

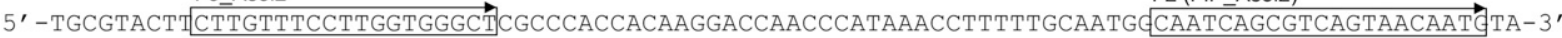
5' -ACGCATGAAGAACAAAGGAACCACCCGAGCGGGTGGTGTTCCTGGTTGGGTATTTGGAAAAACGTTACCGTTAGTCGCAGTCATTGTTACAT-3'

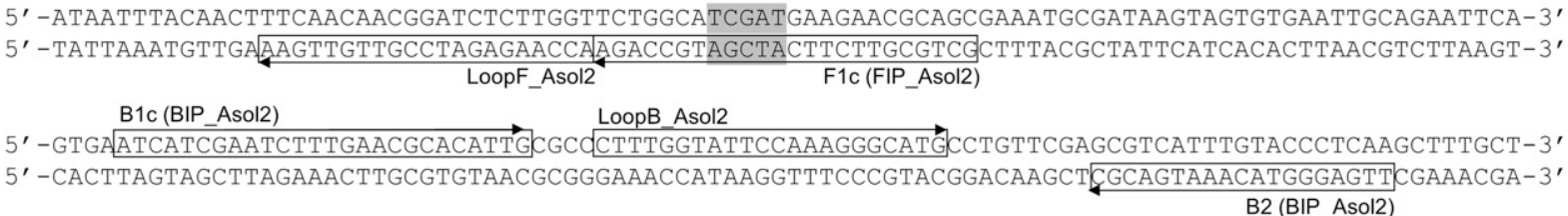

5' -TGGTGTTGGGCGTCTTTTTGTCTCCCCTTGCGGGAGACTCGCCTTAAAGTCATTGGCAGCCGGCCTACTGGTTTCGGAGCGCAGCACAAGTC-3' 5' -ACCACAACCCGCAGAAAAACAGAGGGGAACGCCCTCTGAGCGGAATTTCAGTAACCGTCGGCCGGATGACCAAAGCCTCGCGTCGTGTTCAG-3' B3_Asol2

Fig. 1. Location of loop-mediated isothermal amplification (LAMP) primers within ITS sequence A, PinfL primers: Phytophthora infestans strain IMI66006 (GenBank accession no. AF266779) and B, AsolL primers: Alternaria solani (GenBank accession no. MK493332). A region of sequence not included in the primer design within primer F1c (FIP_Asol2) is shaded in gray. LAMP primer sequences are marked in boxes and detailed in Table 3.

Table 3. Loop-mediated isothermal amplification primers developed for the detection of Phytophthora infestans (PinfL) and Alternaria solani (AsolL)

\begin{tabular}{llc}
\hline Primer sets & \multicolumn{1}{c}{ Sequence (5' to 3') } & Gene location (bp) \\
\hline PinfL primers & Fig. 1 shows nucleotides 1-309 bp & $23-41$ \\
F3_PI1 & TGAACCGTTTCAACCCAAT & $257-274$ \\
B3_PI1 & TTCGCAGCGTTCTTCATC & $(128-150)$ to (74-91) \\
FIP(F1c+F2)PI1 & AAGCTACTAGCTCAGACCGAAGTCTTTATTGCTGGCGGCTA & $(177-202)$ to (238-255) \\
BIP(B1c+B2)PI1 & CTGATTATACTGTGGGGACGAAAGTCATGTGCGAGCCTAGACAT & $108-126$ \\
LoopF_PI1 & CAAACGCTCGCCTTTTGAT & $211-235$ \\
LoopB_PI1 & TAACTAGATAGCAACTTTCAGCAGT \\
AsolL primers & Fig. 1 shows nucleotides 93-460 bp & $102-120$ \\
F3_Asol2 & CTTGTTCCTTGGTGGGCT & $402-422$ \\
B3_Asol2 & AATGACTTTAAGGCGAGTCTC & $(219-242)$ to (162-182) \\
FIP(F1c+F2) Asol2 & GCTGCGTTCTTCTGCCAGACAATCAGCGTCAGTAACAATG & $(281-306)$ to (342-360) \\
BIP(B1c+B2) Asol2 & ATCATCGAATCTTTGAACGCACATTGTTGAGGGTACAAATGACGC & $198-218$ \\
LoopF_Asol2 & ACCAAGAGATCCGTTGTTGAA & $281-306$ \\
LoopB_Asol2 & CTTTGGTATTCCAAAGGGCATG & \\
\hline
\end{tabular}


powered by an electric motor operated from a 12-volt battery. On 14 July 2016, five plants previously inoculated with P. infestans and showing foliar sporulating lesions were placed to either side of the air sampler at distances of $\sim 3 \mathrm{~m}$. The incidence of late blight on all plants within the plot was determined on each sampling occasion.

Four additional air samplers were positioned within a 5-mile radius of the inoculated field plot in commercial potato plots; disease was monitored and samples were taken in the same way. After each sampling period, the two arms were removed from each trap and placed into a 2-ml screw-top tube. DNA was extracted from the samples containing the arms as described previously. P. infestans in extracted DNA samples was then quantified using both real-time LAMP and PCR assays. A similar field plot was established in 2016 and inoculated with A. solani with the intention of monitoring the detection of spores in the same way as for $P$. infestans. However, under Scottish climatic conditions, infections are not guaranteed owing to relatively low average temperatures, and disease did not become established in this year or in subsequent attempts. Air sampling for $A$. solani was, therefore, discontinued.

\section{Results}

Specificity and sensitivity of real-time PCR assay for detection of A. solani. The specificity of primers AsolTQF/AsolTQR and a fluorogenic probe AsolTQP was tested against genomic DNA of 18 isolates of A. solani, nine of A. alternata, and one isolate each of A. dauci, A. tenuissima, A. brassicicola, A. brassicae, and the common potato pathogens $P$. infestans, $R$. solani, $C$. coccodes, $H$. solani, F. culmorum, $F$. sambucinum, $F$. avenaceum, and $F$. coeruleum (Table 2 ).

The real-time assay successfully amplified DNA from all 18 isolates of A. solani tested, but no amplification was observed with DNA from the nine isolates of $A$. alternata or from A. brassicae, A. brassicicola, and A. tenuissima (Table 2). However, the A. solani real-time assay did show cross-reaction with DNA from $A$. dauci. Subsequently, the A. solani PCR primers of Zur et al. (2002) were also tested according to the methods described by those authors and were also found to cross-react with $A$. dauci. The real-time quantitative PCR assay developed in this study reliably detected $200 \mathrm{fg}$ of template DNA of $A$. solani extracted from mycelium per reaction. The standard curve used to calculate the starting concentration of A. solani template DNA had a high correlation coefficient of $R^{2}=$ 0.988 , indicating a reproducible linear response in detection relating to increasing DNA concentration. The efficiency of the assay, calculated from the slope of the standard curve using the regression equation $E=[(10(-1 /$ slope $))-1] \times 100$, was always $>95 \%$.

Real-time LAMP assay specificity and sensitivity for detection of $A$. solani. The specificity of the real-time LAMP AsolL primers was tested against genomic DNA of 31 Alternaria isolates

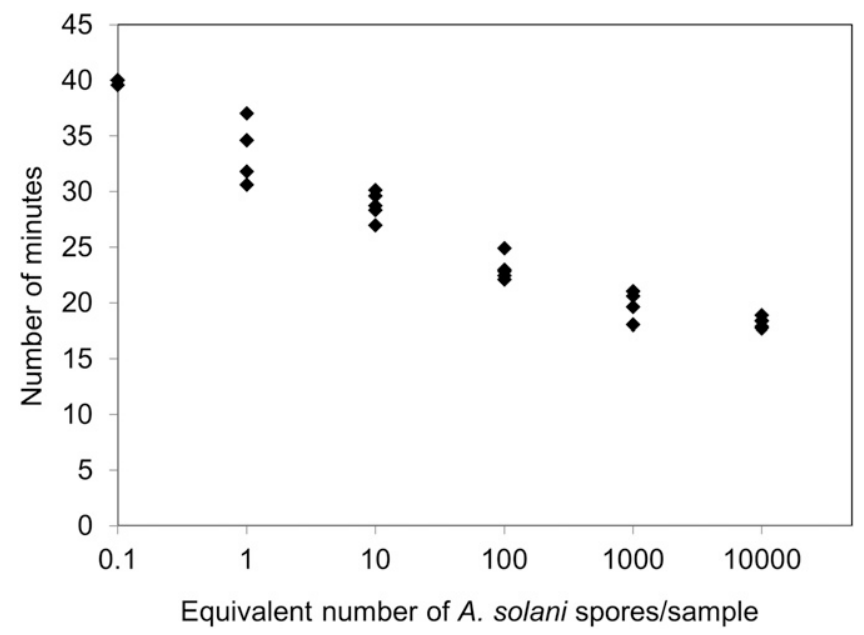

Fig. 2. Time taken (minutes) for the detection of Alternaria solani in a real-time loopmediated isothermal amplification reaction: 40 min indicates no detection. DNA was extracted from suspensions of known $A$. solani spore concentration, and a serial dilution of the DNA was made to the equivalent of $0.1,1,10,100,1,000$, and 10,000 A. solani spores per reaction.
(Table 2). A. solani DNA was consistently amplified, but no amplification of DNA from A. alternata was observed (Table 2). After incubation for $40 \mathrm{~min}$ at $65^{\circ} \mathrm{C}$, detection of DNA extracted from a suspension of known $A$. solani spore concentration and serially diluted to an equivalent of one spore per reaction (equivalent to 4.4 pg of DNA) of $A$. solani was reliably achieved (Fig. 2). No amplification of DNA from A. dauci, A. brassicicola, or any of the other potato pathogens tested was observed, even at DNA concentrations of $50 \mathrm{ng}$ of DNA per reaction assay (equivalent to $\sim 5 \times 10^{4}$ spores of the genus Alternaria per reaction, depending on spore size), using the real-time LAMP assay. In the case of A. tenuissima, amplification was observed at a DNA concentration of $50 \mathrm{ng}$ of DNA per reaction (after $37 \mathrm{~min}$ ) but not at $5 \mathrm{ng}$ of DNA per assay. However, amplification of DNA of $A$. brassicae occurred at $5 \mathrm{ng}$ of DNA per reaction using the real-time LAMP AsolL primers.

Real-time LAMP assay specificity and sensitivity for detection of $\boldsymbol{P}$. infestans. Specificity of the real-time LAMP PinfL primers was tested against genomic DNA of 28 Phytophthora species (Table 1). DNA amplification was consistently observed in $P$. infestans and isolates of the taxonomically closely related species Phytophthora mirabilis, Phytophthora phaseoli, and Phytophthora ipomoea, which were also amplified by the real-time PCR assay of Lees et al. (2012) and the conventional primer set of Trout et al. (1997). Additionally, Phytophthora palmivora (a nonpotato pathogen) amplified close to the threshold of detection after $34 \mathrm{~min}$ of incubation. No amplification of DNA from the potato-infecting species (P. erythroseptica or $P$. nicotianae) occurred. The specificity results shown in Table 1 were obtained by running the real-time LAMP assay for $40 \mathrm{~min}$ at $65^{\circ} \mathrm{C}$.

The $P$. infestans real-time LAMP assay detected $0.5 \mathrm{pg}$ of DNA (equivalent to 0.1 sporangium) in six of eight replicate dilutions and detected $5 \mathrm{pg}$ of DNA (equivalent to one sporangium per reaction) reliably (i.e., this was the lowest concentration of DNA that could be detected in every replicate) (Fig. 3).

Detection of $P$. infestans and $A$. solani spores on air sampling rods. Using real-time PCR, $P$. infestans DNA was reliably detected when one sporangium was artificially added to a simulated air sample (Fig. 4). The real-time LAMP assay reliably detected $P$. infestans when 100 sporangia were added but was less reliable at detecting $P$. infestans when spore numbers were lower (i.e., $P$. infestans was detected in three of four, two of four, and two of four replicates containing 20, 10, and five spores, respectively, using a 40-min incubation period (Fig. 4).

Using real-time PCR, A. solani DNA was also reliably detected when one spore was artificially added to a simulated air sample (Fig. 5). The real-time LAMP assay reliably detected $A$. solani using

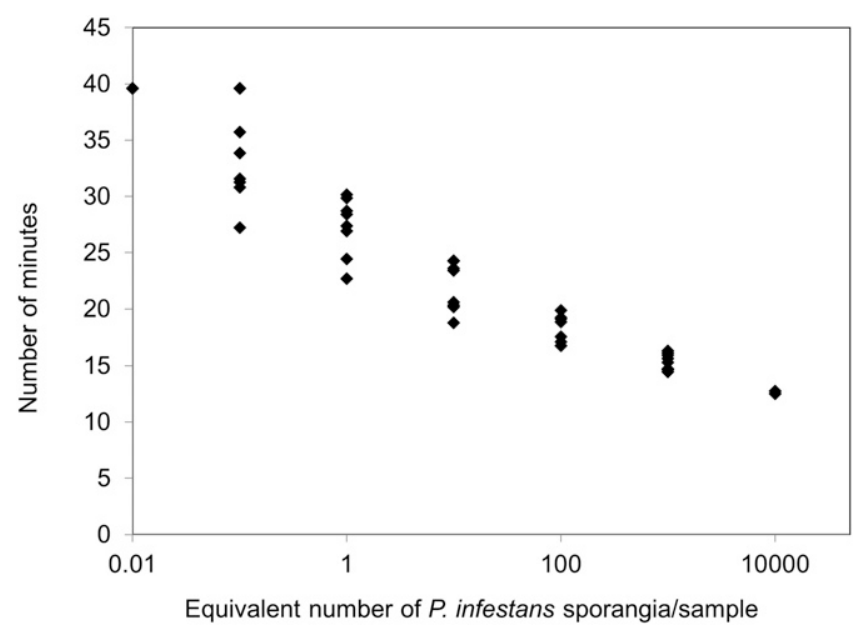

Fig. 3. Time taken (minutes) for the detection of Phytophthora infestans in a real-time loop-mediated isothermal amplification reaction: 40 min indicates no detection. DNA was extracted from suspensions of known $P$. infestans sporangial concentration, and a serial dilution of the DNA was made to the equivalent of $0.01,0.1,1,10$, $100,1,000$, and $10,000 P$. infestans sporangia per reaction. 
a 40-min incubation period when 500 spores were added to a sampling rod (Fig. 5).

It should, however, be noted in both cases that quantification of the number of spores/sporangia detected based on a standard curve created from a singular DNA extraction will be subject to variability, particularly at the lower end of detection. There will be variation between DNA concentrations in the standard curve, spore size will vary, and there is variation between replicates.

In-field detection of $\boldsymbol{P}$. infestans spores. $P$. infestans sporangia (one to two sporangia per sample) were detected using real-time PCR from samples collected from an air sampler placed within the trial plot before late blight symptoms being observed (i.e., before 18 July). The number of sporangia detected increased as disease incidence increased in the plot (Fig. 6). No disease was observed in the commercial fields where the other four samplers were located. Realtime LAMP detection was less sensitive than real-time PCR. When DNA equivalent to 87 sporangia per sample was detected using the real-time PCR, it was also detected using the real-time LAMP assay, consistent with the sensitivity determined in artificially inoculated samples. However, when detection of $P$. infestans using real-time PCR and real-time LAMP assays from DNA extracted from each of the five in-field air samplers was compared (Fig. 7), a close linear relationship $\left(R^{2}=0.90\right)$ between real-time LAMP and real-time PCR detection was observed, indicating that detection using the real-time LAMP assay in practice was more sensitive than the artificially inoculated test samples would suggest.

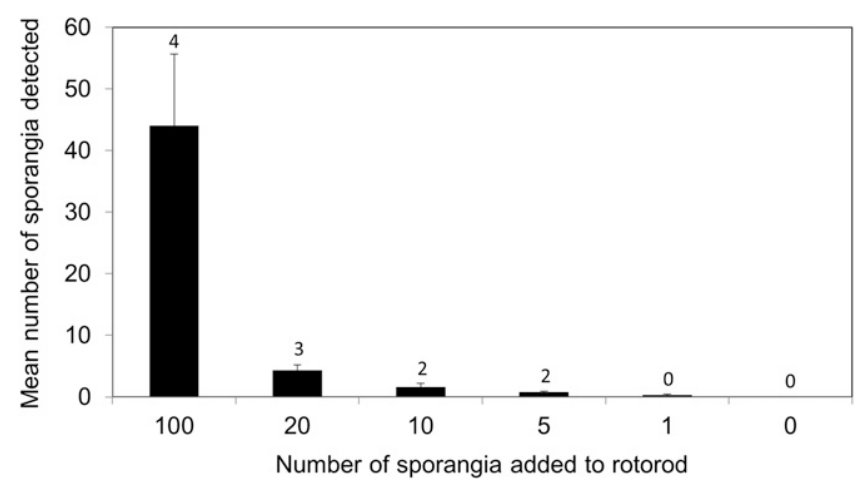

Fig. 4. Mean number of sporangia of Phytophthora infestans detected (plus standard error of mean) using real-time PCR in DNA extracted from rods to which known numbers of sporangia were added. The number above each bar indicates the number of replicates (maximum of four) in which $P$. infestans was detected by realtime loop-mediated isothermal amplification after 40 min of incubation.

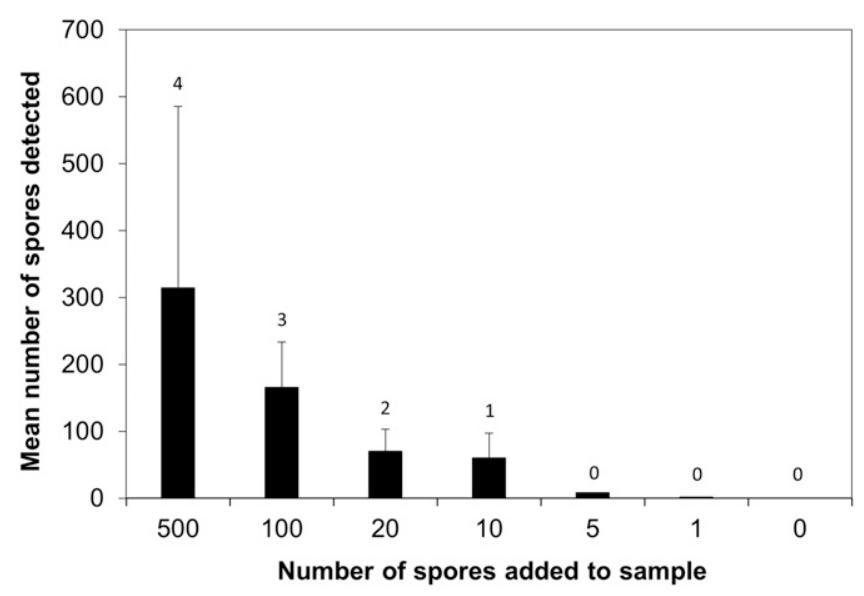

Fig. 5. Mean number of spores of Alternaria solani detected (plus standard error of mean) using real-time PCR in DNA extracted from rods to which known numbers of spores were added. The number above each bar indicates the number of replicates (maximum of four) in which $A$. solani was detected by real-time loop-mediated isothermal amplification after $40 \mathrm{~min}$ of incubation.
As stated previously, repeated attempts were made unsuccessfully to establish an early blight epidemic in the field, and no in-field spore detection data are, therefore, available for A. solani.

\section{Discussion}

In this study, sensitive and specific real-time LAMP assays capable of detecting DNA equivalent to one sporangium of $P$. infestans and one spore of $A$. solani were developed.

Two LAMP assays have been published for the detection of $P$. infestans in leaf tissue, but neither demonstrated detection of sporangia in air samples. Hansen et al. (2016) designed LAMP primers for $P$. infestans, which cross-reacted with $P$. nicotianae using the ITS2 region. These authors went on to design more specific primers using the Rgn86_2 but found reduced sensitivity (200 pg of DNA), even with an incubation period of $1 \mathrm{~h}$. They found no way to discriminate $P$. infestans from $P$. mirabilis, although they did manage to eliminate cross-reactivity with $P$. ipomoea and $P$. phaseoli. Another real-time

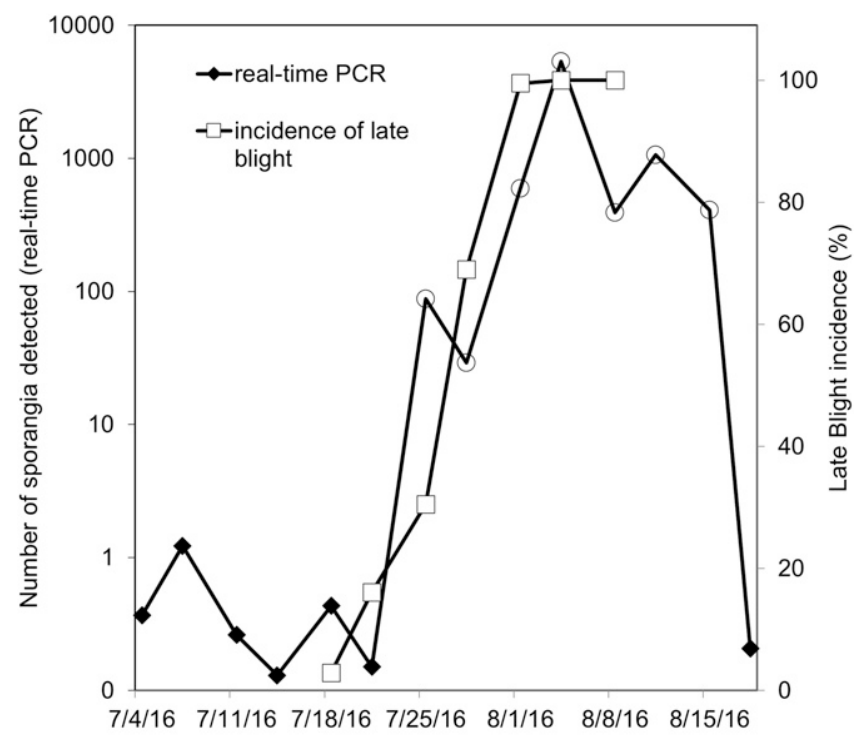

Date

Fig. 6. Detection of Phytophthora infestans sporangia using real-time PCR on DNA extracted from samples collected at 3- to 4-day intervals with an air sampler located in a late blight trial plot. Samples detectable using both real-time PCR and loop-mediated isothermal amplification are shown with the symbol C.

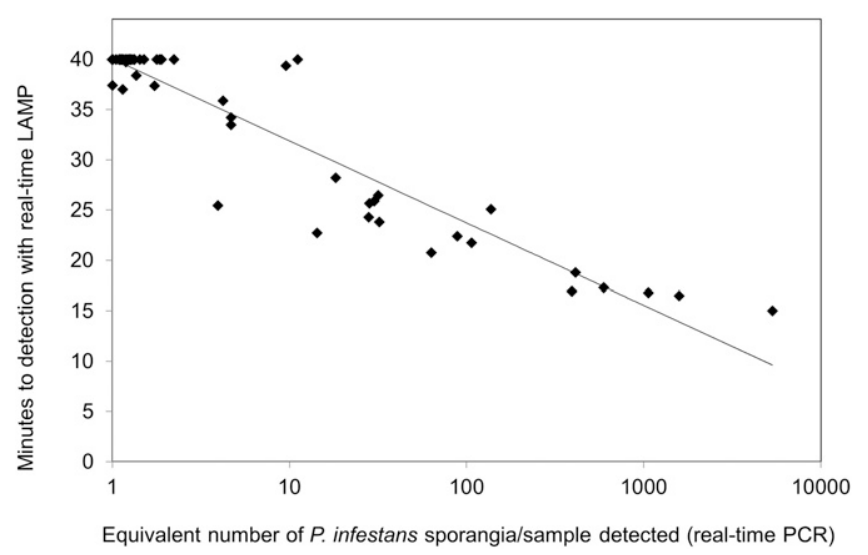

Fig. 7. Relationship between the number of sporangia of Phytophthora infestans detected using real-time PCR in DNA extracted from airborne samplers deployed at five sites in Scotland in 2016 and detection of sporangia with real-time loopmediated isothermal amplification (LAMP). Detection using the real-time LAMP assay is presented as time taken (maximum $40 \mathrm{~min}$ ) until detection of $P$. infestans DNA. Data are presented on a logarithmic scale $\left(R^{2}=0.90\right)$. 
LAMP assay developed for P. infestans (Si Ammour et al. 2017) also showed cross-reaction with the nonpotato pathogens $P$. mirabilis, $P$. ipomoea, and $P$. phaseoli in agreement with the work presented here. In addition, we also observed cross-reactivity with the non-potato pathogen $P$. palmivora, which was not included in the specificity testing of the assays designed by either Hansen et al. (2016) or Si Ammour et al. (2017). Both the assay described in this paper and that of Si Ammour et al. (2017) target the ITS2 region, although the primer sequences are different, and both have increased sensitivity compared with the assay of Hansen et al. (2016).

To our knowledge, this is the first published real-time LAMP assay developed for A. solani spores. A comparison of LAMP and PCR-based assays for the detection of A. solani (Khan et al. 2018) demonstrated sensitivity of a LAMP assay based on the histidine kinase gene (HK1) of $1.36 \mathrm{ng}$ per reaction using DNA extracted from fungal cultures compared with a greater sensitivity of 5 pg per reaction (equivalent to one spore) demonstrated in this work.

Additionally, a real-time PCR assay was developed for A. solani, and was shown to discriminate $A$. solani and $A$. alternata but had some cross-reactivity with $A$. dauci. Subsequent testing showed that a previously published conventional PCR assay (Zur et al. (2002) also cross-reacted with $A$. dauci. An A. solani real-time PCR assay previously reported by Leiminger et al. (2015) also showed crossreactivity with $P$. infestans and other potato and nonpotato pathogens. These authors used intensity of SYBR Green fluorescence to quantify target DNA after amplification and used their assay to demonstrate relationships between pathogen detection and disease development in planta, but they did not explore spore detection.

Many existing decision support systems for disease control in a range of cropping systems assume the presence of inoculum during favorable environmental conditions. However, for air-dispersed plant pathogens, numerous factors can act on the seasonal timing of airborne inoculum release and spread. Air sampling combined with target pathogen detection (laboratory-based PCR techniques) has been deployed in cropping systems as a means of assessing inoculum presence to inform disease control strategies (Brachaczek et al. 2016; Cao et al. 2016; Fall et al. 2015b; Gent et al. 2009; Kunjeti et al. 2016). Fall et al. (2015a) highlighted the need for detection of airborne inoculum in decision support systems for $P$. infestans and developed a real-time PCR, which detected sporangia (Fall et al. 2015b). This assay is comparable with that of Lees et al. (2012) with respect to specificity and as demonstrated in this paper, also with respect to detection of sporangia. Although real-time PCR techniques may provide the gold standard in terms of sensitivity for detection, the need for thermocycling makes the incorporation of real-time PCR methodology into the development of in-field detection devices problematic. However, combining the trapping of airborne inoculum with isothermal detection assays, such as LAMP, integrated into infield devices can be used as a way of alerting growers to disease risk periods and an aid to control disease through the efficient use of fungicides. For example, Villari et al. (2017) demonstrated how the capture of airborne inoculum of Magnaporthe oryzae, the causal pathogen of gray leaf spot of perennial ryegrass, in a spore trap in conjunction with pathogen detection using a real-time LAMP assay could be used in disease risk forecasting. Thiessen et al. (2016) validated the effectiveness of spore trapping and detection of Erysiphe necator (causing grape powdery mildew) to determine presence of inoculum and thus, initiate fungicide applications compared with a standard practice that was based on host development rather than inoculum presence. They found a reduction on average of 3.3 fungicide applications when applications were initiated using the inoculum detection system compared with standard practice without any increase in disease symptoms.

Current weather-based disease risk models and predictions for late blight and early blight could potentially be enhanced through early in-field detection of $P$. infestans and Alternaria spp., leading to improved decision-making ability for growers with respect to fungicide choice and application and therefore, more efficient resource use. In this paper, real-time LAMP assays for the detection of airborne spores of $P$. infestans and $A$. solani were developed, and an ability to capture sporangia of $P$. infestans in the field and detect them was demonstrated, suggesting that it is suitable for incorporation into automated in-field isothermal detection devices designed for this purpose. Similarly, as in-field real-time PCR instrumentation becomes increasingly available, the sensitive real-time PCR assays for $P$. infestans and A. solani described in this paper could be more readily deployed. Additional research would be required to test and ensure appropriate sensitivity of the assays for automated detection and risk forecasting in combination with optimal air sampling methodologies. In combination with improved weather-based disease risk forecasts for late blight, such as the Hutton criteria (Dancey et al. 2017), infection risk models that provide a framework for quantifying the impact of future climates on the risk of disease occurrence and spread (Skelsey et al. 2016) and the development of a simple and robust tool for forecasting the risk of between-field spread of disease based on the viability of dispersing inoculum (Skelsey et al. 2018) new diagnostic tools may contribute to improvements in the accuracy of disease risk warning systems for late blight, or indeed any crop pathosystem which is characterized by airborne inoculum.

\section{Acknowledgments}

We thank Dr. Jonathan West at Rothamsted Research for the loan of air samplers and colleagues listed in Tables 1 and 2 for supply of isolates, which are held under Science \& Advice for Scottish Agriculture license number PH/16/2016. We also thank Adam Burzyński (Novazym Polska) for assistance with the loopmediated isothermal amplification assay design.

\section{Literature Cited}

Ardestani, S. T., Sharifnabi, B., Zare, R., and Moghadam, A. A. 2010. New Alternaria species associated with potato leaf spot in various potato growing regions of Iran. Iran J. Plant Pathol. 45:83-86.

Böhm, J., Hahn, A., Schubert, R., Bahnweg, G., Adler, N., Nechwatal, J., Oehlmann, R., and Obszwald, W. 1999. Real-time quantitative PCR: DNA determination in isolated spores of the mycorrhizal fungus Glomus mosseae and monitoring of Phytophthora infestans and Phytophthora citricola in their respective host plants. J. Phytopathol. 147:409-416.

Brachaczek, A., Kaczmarek, J., and Jedryczka, M. 2016. Monitoring blackleg (Leptosphaeria spp.) ascospore release timing and quantity enables optimal fungicide application to improved oilseed rape yield and seed quality. Eur. J. Plant Pathol. 145:643-657.

Cao, X., Yao, D., Zhou, Y., West, J. S., Xu, X., Luo, Y., Ding, K., Fan, J., and Duan, X. 2016. Detection and quantification of airborne inoculum of Blumeria graminis f. sp. tritici using quantitative PCR. Eur. J. Plant Pathol. 146:225-229.

Cooke, D. E. L., Cano, L. M., Raffaele, S., Bain, R. A., Cooke, L. R., Etherington, G. J., Deahl, K. L., Farrer, R. A., Gilroy, E. M., Goss, E. M., Grünwald, N. J., Hein, I., MacLean, D., McNicol, J. W., Randall, E., Oliva, R. F., Pel, M. A., Shaw, D. S., Squires, J. N., Taylor, M. C., Vleeshouwers, V. G. A. A., Birch, P. R. J., Lees, A. K., and Kamoun, S. 2012. Genome analyses of an aggressive and invasive lineage of the Irish potato famine pathogen. PLoS Pathog 8:e1002940.

Cooke, L. R., Schepers, H. T. A. M., Hermansen, A., Bain, R. A., Bradshaw, N. J., Ritchie, F., Shaw, D. S. A., Evenhuis, A., Kessel, G. J. T., Wander, J. G. N., Andersson, B., Hansen, J. G., Hannukkala, A., Nærstad, R., and Nielsen, B. J. 2011. Epidemiology and integrated control of potato late blight in Europe. Potato Res. 54:183-222.

Dancey, S. R., Skelsey, P., and Cooke, D. E. L. 2017. The Hutton Criteria: A classification tool for identifying high risk periods for potato late blight disease development in Great Britain. In: Proceedings of the 16th EuroBlight Workshop. PPO special report no. 18.

Edin, E. 2012. Species specific primers for identification of Alternaria solani, in combination with analysis of the F129L substitution associated with loss of sensitivity toward strobilurins. Crop Prot. 38:72-73.

Edin, E., and Andersson, B. 2014. The early blight in Sweden-species abundance and strobilurin sensitivity. Pages 83-84 in Proceedings of the 14th EuroBlight Workshop. PPO special report no. 16. H. T. A. M. Schepers, ed.

Fall, M. L., Tremblay, D. M., Gobeil-Richard, M., Couillard, J., Rocheleau, H., Van der Heyden, H., Lévesque, C. A., Beaulieu, C., and Carisse, O. 2015a. Infection efficiency of four Phytophthora infestans clonal lineages and DNAbased quantification of sporangia. PLoS One 10:e136312.

Fall, M. L., Van der Heyden, H., Brodeur, L., Leclerc, Y., Moreau, G., and Carisse, O. 2015b. Spatiotemporal variation in airborne sporangia of Phytophthora infestans: Characterization and initiatives towards improving potato late blight risk estimation. Plant Pathol. 64:178-190.

Fry, W. 2008. Phytophthora infestans: The plant (and R gene) destroyer. Mol Plant Pathol. 9:385-402.

Gent, D. H., Nelson, M. E., Farnsworth, J. L., and Grove, G. G. 2009. PCR detection of Pseudoperonospora humuli in air samples from hop yards. Plant Pathol. 58:1081-1091. 
Gudmestad, N. C., Arabiat, S., Miller, J. S., and Pasche, J. S. 2013. Prevalence and impact of SDHI fungicide resistance in Alternaria solani. Plant Dis. 97: 952-960.

Hansen, Z. R., Knaus, B. J., Tabima, J. F., Press, C. M., Judelson, H. S., Grünwald, N. J., and Smart, C. D. 2016. Loop-mediated isothermal amplification for detection of the tomato and potato late blight pathogen, Phytophthora infestans. J. Appl. Microbiol. 120:1010-1020.

Haverkort, A. J., Boonekamp, P. M., Hutten, R., Jacobsen, E., Lotz, L. A. P., Kessel, G. J. T., Visser, R. G. F., and van der Vossen, E. A. G. 2008. Societal costs of late blight in potato and prospects of durable resistance through cisgenic modification. Potato Res. 51:47-57.

Hussain, S., Lees, A. K., Duncan, J. M., and Cooke, D. E. L. 2005. Development of a species-specific and sensitive detection assay for Phytophthora infestans and its application for monitoring of inoculum in tubers and soil. Plant Pathol. 54: 373-382.

Judelson, H. S., and Tooley, P. W. 2000. Enhanced polymerase chain reaction methods for detecting and quantifying Phytophthora infestans in plants. Phytopathol. 90:1112-1119.

Kemmitt, G. 2002. Early blight of potato and tomato. Plant Health Instructor. doi: 10.1094/PHI-I-2002-0809-01.

Khan, M., Wang, R., Li, B., Liu, P., Weng, Q., and Chen, Q. 2018. Comparative evaluation of the LAMP assay and PCR-based assays for the rapid detection of Alternaria solani. Front. Microbiol. 9:2089.

Kunjeti, S. G., Anchieta, A., Martin, F. N., Choi, Y.-J., Thines, M., Michelmore, R. W., Koike, S. T., Tsuchida, C., Mahaffee, W., Subbarao, K. V., and Klosterman, S. J. 2016. Detection and quantification of Bremia lactucae by spore trapping and quantitative PCR. Phytopathol. 106:1426-1437.

Lees, A. K., Sullivan, L., Lynott, J. S., and Cullen, D. W. 2012. Development of a quantitative real-time PCR assay for Phytophthora infestans and its applicability to leaf, tuber and soil samples. Plant Pathol. 61:867-876.

Leiminger, J. H., Adolf, B., and Hausladen, H. 2014. Occurrence of the F129L mutation in Alternaria solani populations on Germany in response to QoI application, and its effect on sensitivity. Plant Pathol. 63:640-650.

Leiminger, J. H., Bäßler, E., Knappe, C., Bahnweg, G., and Hausladen, H. 2015. Quantification of disease progression of Alternaria spp. on potato using realtime PCR. Eur. J. Plant Pathol. 141:295-309.

Leiminger, J. H., and Hausladen, H. 2012. Early blight control in potato using disease-orientated threshold values. Plant Dis. 96:124-130.

Llorente, B., Bravo-Almonacid, F., Cvitanich, C., Orlowska, E., Torres, H. N., Flawiá, M. M., and Alonso, G. D. 2010. A quantitative real-time PCR method for in planta monitoring of Phytophthora infestans growth. Lett. Appl. Microbiol. 51:603-610.

Notomi, T., Okayama, H., Masubuchi, H., Yonekawa, T., Watanabe, K., Amino, N., and Hase, T. 2000. Loop-mediated isothermal amplification of DNA. Nucleic Acids Res. 28:e63.

Odilbekov, F., Carlson-Nilsson, U., and Liljeroth, E. 2014. Phenotyping early blight resistance in potato cultivars and breeding clones. Euphytica 197:87-97.

Pasche, J. S., and Gudmestad, N. C. 2008. Prevalence, competitive fitness and impact of the F129L mutation in Alternaria solani from the United States. Crop Prot. 27:427-435.

Pavón, M. Á., González, I., Martín, R., and García, T. 2012. A real-time reversetranscriptase PCR technique for detection and quantification of viable Alternaria spp. in foodstuffs. Food Control 28:286-294.

Raeder, U., and Broda, P. 1985. Rapid preparation of DNA from filamentous fungi. Lett. Appl. Microbiol. 1:17-20.

Rodrigues, T. T. M. S., Berbee, M. L., Simmons, E. G., Cardoso, C. R., Reis, A., Maffia, L. A., and Mizubuti, E. S. G. 2010. First report of Alternaria tomatophila and A. grandis causing early blight on tomato and potato in Brazil. New Dis. Rep. 22:28.
Rosenzweig, N., Olaya, G., Atallah, Z. K., Cleere, S., Stanger, C., and Stevenson, W. R. 2008. Monitoring and tracking changes in sensitivity to azoxystrobin fungicide in Alternaria solani in Wisconsin. Plant Dis. 92: 555-560.

Runno-Paurson, E., Loit, K., Hansen, M., Tein, B., Williams, I. H., and Mand, M. 2015. Early blight destroys potato foliage in the northern Baltic region. Acta Agr. Scand. Section B Soil Plant Sci. 65:422-432.

Si Ammour, M. S., Bilodeau, G. J., Tremblay, D. M., Van der Heyden, H., Yaseen, T., Varvaro, L., and Carisse, O. 2017. Development of real-time isothermal amplification assays for on-site detection of Phytophthora infestans in potato leaves. Plant Dis. 101:1269-1277.

Skelsey, P., Cooke, D. E. L., Lynott, J. S., and Lees, A. K. 2016. Crop connectivity under climate change: Future environmental and geographic risks of potato late blight in Scotland. Glob. Change Biol. 22:3724-3738.

Skelsey, P., Dancey, S. R., Preedy, K., Lees, A. K., and Cooke, D. E. L. 2018 Forecasting the spread of aerially transmitted crop diseases with a binary classifier for inoculum survival. Plant Pathol. 67:920-928.

Skelsey, P., and Newton, A. C. 2015. Future environmental and geographic risks of Fusarium head blight of wheat in Scotland. Eur. J. Plant Pathol. 142: 133-147.

Skelsey, P., Rossing, W. A. H., Kessel, G. J. T., and van der Werf, W. 2009. Scenario approach for assessing the utility of dispersal information in decision support for aerially spread plant pathogens, applied to Phytophthora infestans. Phytopathol. 99:887-895.

Skelsey, P., Rossing, W. A. H., Kessel, G. J. T., and van der Werf, W. 2010 Invasion of Phytophthora infestans at the landscape level: How do spatial scale and weather modulate the consequences of spatial heterogeneity in host resistance? Phytopathol. 100:1146-1161.

Spitters, C. J. T., van Keulen, H., and van Kraalingen, D. W. G. 1989. A simple and universal crop growth simulator: SUCROS87. Pages 147-181 in: Simulation and Systems Management in Crop Protection. R. Rabbinge, S. A. Ward, and H. H. van Laar, eds. Pudoc, Wageningen, The Netherlands.

Stewart, H. E., Bradshaw, J. E., Wastie, R. L., Mackay, G. R., Erlich, O., Livescu, L., and Nachmias, A. 1994. Assessing progenies of potato for resistance to early blight. Potato Res. 37:257-269.

Thiessen, L. D., Keune, J. A., Neill, T. M., Turechek, W. W., Grove, G. G., and Mahaffee, W. F. 2016. Development of a grower-conducted inoculum detection assay for management of grape powdery mildew. Plant Pathol. 65:238-249.

Trout, C. L., Ristaino, J. B., Madritch, M., and Wangsomboondee, T. 1997. Rapid detection of Phytophthora infestas in late-blight infected potato and tomato using PCR. Plant Dis. 81:1042-1048.

Villari, C., Mahaffee, W. F., Mitchell, T. K., Pedley, K. F., Pieck, M. L., and Hand, F. P. 2017. Early detection of airborne inoculum of Magnaporthe oryzae in turfgrass fields using a quantitative LAMP assay. Plant Dis. 101:170-177.

Wharton, P., Fairchild, K., Belcher, A., and Wood, E. 2012. First report of in vitro boscalid-resistant isolates of Alternaria solani causing early blight of potato in Idaho. Plant Dis. 96:454.

Yellareddygari, S. K. R., Taylor, R. J., Pasche, J. S., Zhang, A., and Gudmestad, N. C. 2018. Predicting potato tuber yield loss due to early blight severity in the Midwestern United States. Eur. J. Plant Pathol. 152:71-79.

Zheng, H. H., Zhao, J., Wang, T. Y., and Wu, H. 2014. Characterisation of Alternaria species associated with potato foliar diseases in China. Plant Pathol. 64:425-433.

Zur, G., Shimoni, E. M., Hallerman, E., and Kashi, Y. 2002. Detection of Alternaria fungal contamination in cereal grains by a polymerase chain reaction-based assay. J. Food Prot. 65:1433-1440.

Zwankhuizen, M. J., and Zadoks, J. C. 2002. Phytophthora infestans's 10-year truce with Holland: A long-term analysis of potato late-blight epidemics in the Netherlands. Plant Pathol. 51:413-423. 